\title{
Perception of the HACCP system operators on livestock product manufacturers
}

\author{
Jung-Hyun Kim ${ }^{1}$, Ki-Chang Nam², Cheorun Jo ${ }^{3}$ and Dong-Gyun Lim
}

\begin{abstract}
The purpose of this study was to investigate crucial factors on HACCP system implementation in domestic livestock product plants, and to offer job satisfaction and the career prospect of HACCP system operators. The survey was carried out by selecting 150 HACCP system operators who implemented HACCP system. The respondents claimed that the most important contents in HACCP system operation were to assemble HACCP team (21.8\%), and the second was to monitoring (20.0\%). Documentation and recording (16.9\%) and verification (11.1\%) were followed. The respondents answered the major factor in sanitation management was cleaning/washing/disinfection (18.9\%) and inspection (18.4\%). The results showed that there were significant differences in the prospect of occupation in HACCP system operator by the gender $(p<0.015)$, age, livestock product facilities, service period, and position $(p<0.001)$. The respondents from HACCP system operator were satisfied with their job $(73 \%)$ and also showed optimistic prospect of occupation (82\%).
\end{abstract}

Keywords: HACCP system operator, Livestock product plants, Survey, Monitoring, Prospect of occupation

\section{Background}

The safety of food products has become a major issue of concern. Hazard analysis critical control points (HACCP) is a food safety management system [1], widely acknowledged as the best method of assuring product safety while becoming internationally recognized as a tool for controlling food borne safety hazards (Codex Alimentarius Commission, [2,3]). HACCP is a systematic approach to the identification, evaluation, and control of hazards in those steps in food manufacturing that is critical to food safety (Ropkins et al., [4]).

In several countries, including Korea, hazard analysis critical control point (HACCP) systems have been introduced with regard to product hygiene and safety (Codex Alimentarius Commission, [5]). In Korea, regulatory authorities have introduced HACCP systems on meat processing plant in 1997, slaughter house in 2000, livestock product plant in 2001, milk processing plant, meat sale and distribution in 2004, feed mill in 2005, and animal farm in 2006 [6]. HACCP implementation of the slaughterhouse in livestock product field is only mandatory in

\footnotetext{
* Correspondence: tousa0994@naver.com

${ }^{4}$ Department of Health Administration and Food Hygiene, Jinju Health College, Jinju 660-757, Korea

Full list of author information is available at the end of the article
}

Korea. The HACCP system is being increasingly used in many food industries under regulatory agencies. Most developed countries including USA (1998), EU (1996) and Australia (1997) are implementing HACCP system as an obligation.

It is doubtful if any company can implement HACCP without trained-HACCP team members. This is particularly true for the small-scale company with limited access to information [7]. Competency in HACCP can be effectively gained through training and this must be complemented with the appropriate knowledge of food sanitation and food microbiology. Research has observed that the employment of an experienced, technically qualified person is the single most important factor influencing the implementation of HACCP [8].

The studies on HACCP have recently focused on evaluation of sanitation management performance, benefits of HACCP implementation, and employees' knowledge and performance degree of HACCP in school foodservice sector [9-11]. In the livestock products sector, economic feasibility of HACCP at slaughterhouse [12], and comparative analysis of the prerequisite items for HACCP in livestock product plants [13] have been reported. However, there has not yet been studied about the basic information for job order of priority and career prospect of HACCP 
system operators (HACCP and microbiological analysis operator) in livestock products sector. Therefore, the objective of this study was not only to investigate crucial factors on HACCP system implementation in domestic livestock product plants, but also to offer job satisfaction and the career prospect of HACCP system operators in livestock product industry.

\section{Methods}

\section{Study population}

This study was based on data obtained 15 livestock product manufacturer (5 large scale plants, 10 medium scale plants) located in Korea. A survey was conducted with subjects to operate HACCP in livestock product plants. Most of the respondents were HACCP team members (HACCP and microbiological analysis operators) who are in charge of quality control department of the manufacturer. The survey was carried out with 150 respondents who implemented HACCP system. The survey questionnaire was performed by some questions with multiple choices for the answers and consisted of 11 questions including 7 questions of general characteristics, 2 questions of priority of duties in HACCP system operation in plants and 2 questions of a job analysis.

\section{Description of demographic variables}

In the study, demographic variable included gender, age, educational and income level, size of livestock product facilities, service period, and position. Age reported at the time of interview was categorized into three groups: less than 29, 30-39, and 40-49. Educational level was divided into college and university. Income level per month was categorized into four groups: less than 200, 200 to 250, 250 to 300 , and more than 300 Korean won. Livestock product facilities were divided into two categories: smallor medium and large-scale. The service period was classified into three groups: less than 1, 3-5, and 5-10 years. Position was categorized into four groups: employees, team manager, assistant manager, and president, director. All participants provided written and informed consent to participate in the study. Respondents were individually given adequate time to answer each query in writing.

\section{Statistical analysis}

Statistical analysis was performed using the STATA software (version12.0) for Window and Two-sided P-value $<0.05$ was considered statistically significant. General characteristics of the study participants and priority of duties in HACCP system operation and sanitation management are presented as frequency and percentage. The chi-square tests were performed to investigate the differences among job satisfaction and prospect of occupation in HACCP system operators by age, educational and income level, size of food product facilities, career, and position.

\section{Results and discussion}

General characteristics of the study participants are shown in Table 1. Overall, male subjects are 68\% and female ones are $32 \%$. Among age variable, age is $20-29$ (46.7\%), 30-39 (33.3\%), and 40-49 (20\%) respectively. In educational level, the respondents have acquired a college diploma (58.7\%) or university degree (41.3\%). Income level per month is under the 3 million won (35.3\%), 2 million won (29.3\%), 2.5 million won (25.3\%), and over 3 million won (10.0\%). Size of livestock product facilities is; small and mediumscale facilities were mostly $73.3 \%$ and large-scale ones were respectively $26.7 \%$. Career duration is; the highest was less than 1 year (56.7\%), whereas 3-5 year was the lowest $(8.7 \%)$ under a year workers have been working as a current HACCP system operators in manufactures. The position is employees $(53.3 \%)$, team manager $(28 \%)$, assistant manager (17.3\%) and president (CEO) (1.3\%).

Table 2 shows the priority of duties in HACCP system operation in plants. Basically, HACCP system is a science-

Table 1 General characteristics of respondents participated ( $N=\mathbf{1 5 0})$

\begin{tabular}{|c|c|c|c|}
\hline Characteristics & & Frequency (N) & Percent (\%) \\
\hline \multirow[t]{2}{*}{ Gender } & Male & 102 & 68 \\
\hline & Female & 48 & 32 \\
\hline \multirow[t]{3}{*}{ Age } & $20-29$ & 70 & 46.7 \\
\hline & $30-39$ & 50 & 33.3 \\
\hline & $40-49$ & 30 & 20.0 \\
\hline \multirow{2}{*}{$\begin{array}{l}\text { Educational } \\
\text { background }\end{array}$} & zCollege diploma & 88 & 58.7 \\
\hline & University degree & 62 & 41.3 \\
\hline \multirow{4}{*}{$\begin{array}{l}\text { Income per month } \\
\text { (million won) }\end{array}$} & $<2$ & 44 & 29.3 \\
\hline & $<2.5$ & 38 & 25.3 \\
\hline & $<3$ & 53 & 35.3 \\
\hline & $\geq 3$ & 15 & 10.0 \\
\hline \multirow{2}{*}{$\begin{array}{l}\text { Size of processing } \\
\text { facilities }\end{array}$} & Large-scale & 40 & 26.7 \\
\hline & $\begin{array}{l}\text { Small and } \\
\text { medium-scale }\end{array}$ & 110 & 73.3 \\
\hline \multirow[t]{3}{*}{ Service period (yrs.) } & $<1$ & 85 & 56.7 \\
\hline & $3-5$ & 13 & 8.7 \\
\hline & $5-10$ & 52 & 34.7 \\
\hline \multirow[t]{4}{*}{ Position } & Employees & 2 & 53.3 \\
\hline & Team manager & 42 & 28 \\
\hline & Assistant manager & 26 & 17.3 \\
\hline & President, CEO & 80 & 1.3 \\
\hline Total & & 150 & 100 \\
\hline
\end{tabular}




\begin{tabular}{|c|c|c|}
\hline HACCP system operation & Frequency (N) & Percent (\%) \\
\hline Assemble HACCP team & 98 & 21.8 \\
\hline Monitoring & 90 & 20.0 \\
\hline Documentation and recording & 76 & 16.9 \\
\hline Verification & 50 & 11.1 \\
\hline Establish a corrective actions & 29 & 6.4 \\
\hline Establish critical limits for each CCP & 28 & 6.2 \\
\hline $\begin{array}{l}\text { Describe product and identify } \\
\text { intended use }\end{array}$ & 27 & 6.0 \\
\hline $\begin{array}{l}\text { Construct flow diagram and on-site } \\
\text { confirmation of it }\end{array}$ & 20 & 4.4 \\
\hline Conduct a Hazard Analysis & 17 & 3.8 \\
\hline CCP determination & 15 & 3.3 \\
\hline Total & 450 & 100 \\
\hline
\end{tabular}

based system created to identify specific hazards and actions to control them in order to ensure food safety. It is also a systematic process: a sequence of twelve tasks has been described, in which the seven basic HACCP principles are included (Codex Alimentarius Commission, [14]). The respondents claimed that the most important contents in HACCP system operation were to assemble HACCP team (21.8\%), and the second was to monitoring (20.0\%). Documentation and recording (16.9\%) and verification (11.1\%) were followed. The reason for choosing first on assembling HACCP team might be due to the size of food companies. While relatively large-scale manufacturer will find it easier to find human resource and technical assistance, small and medium-scale businesses find it more difficult because they lack appropriate human resources, technical knowledge and experience to introduce HACCP into practice. Particularly, small food processors tend to employ the staff they need to carry out production tasks, to think only in terms of productivity rather than safety and to understand the HACCP system as complicated and unnecessary to produce food products. Therefore, the introduction of HACCP into these companies is more difficult than in large ones to use HACCP $[15,16]$. It is confirmed that small-scale ones were less likely to invest in hygiene and food safety than larger ones [17]. Thus, HACCP operator with the ability to manage if the HACCP system is working correctively is urgently required.

Monitoring in HACCP means checking that the preventative measure at a $\mathrm{CCP}$ is under control to prevent hazard [18]. Monitoring was the second selected reason (20.0\%) for the implementation of the HACCP system. The third most frequent given reason was a documentation and recording (16.9\%). Records related to steps and procedures of HACCP must be fully completed and signed by responsible person, which adds an extra task to the routine work of food processing. Managers and staff, particularly in small businesses, require a great deal of paper work [19]. Verification was the fourth selected reason $(11.1 \%)$ for the implementation of the HACCP system. The Codex Alimentarius defines verification as the application of methods, procedures, tests and other evaluations in addition to monitoring to determine compliance with the HACCP plan [19]. As stated in the sixth principles, verification includes all activities (e. g. auditing, food analysis and test), which are focused on determining that all health hazards are controlled [19]. As mentioned in Table 2, 4.4\% reported to have a constructing flow diagram and on-site confirmation of it. Food factory layout must be designed to achieve a smooth flow of operations keeping the amount of handling of food materials to the minimum possible.

The World Health Organization has published a definition for prerequisites (WHO, [20]) "practices and conditions needed prior to and during the implementation of HACCP and which are essential for food safety" and again mentions that these are described in Codex Alimentairus Commission's General Principles of Food Hygiene and other Codes of Practice. The concepts of prerequisite program (PRP) and how it will benefit HACCP had been reported by Wallace and Williams [21]. It has been recommended that before HACCP is utilized, a prerequisite program is needed [22].

Table 3 lists the priority of duties in sanitation management related to pre-requisites programs in plants. Sanitation management consisted of 11 tasks, where the importance of the field is hygiene control. Duties of importance are like these; cleaning/washing/disinfection (18.9\%), inspection (18.4\%), water supply (16.4\%), pest control (10.9\%), and employee hygiene (7.8\%). It can be quite affected an entire sanitation management such as cleaning, washing and sterilizing; cause by neglecting the

Table 3 Priority of duties in sanitation management in plants

\begin{tabular}{lcc}
\hline Sanitation management & Frequency (N) & Percent (\%) \\
\hline Cleaning/Washing/disinfection & 85 & 18.9 \\
Inspection & 83 & 18.4 \\
Water supply & 74 & 16.4 \\
Pest control & 49 & 10.9 \\
Employee hygiene & 35 & 7.8 \\
Ventilation & 34 & 7.6 \\
Record of receiving raw materials & 29 & 6.4 \\
Facility and equipment & 28 & 6.2 \\
Transportation & 16 & 3.6 \\
Recall & 13 & 2.9 \\
Storage & 4 & 0.9 \\
Total & 450 & 100 \\
\hline
\end{tabular}


management of hygiene. For example, it could be caused germs; dirt hands, a rust knife, cutting board and bacterial pollution. That is, it is thought that they were required to have high level of sanitary duties; keeping a clean knife, sterilizing cutting board, and washing hands for the final product of the process. Equipment should also be designed and constructed so that cleaning, maintenance and inspection are facilitated. Well designed and structured premises with reliable equipment could help in maintaining hygienic conditions, improving cleanliness and cleaning effectiveness and controlling pest infestations [23]. However, food premises with congested and unhygienically designed food preparation rooms are frequently found. Normally, this is the case in small businesses that have been increasing their productivity without the consequent expansion of their facilities and installations, or businesses that are crowded with staff and machinery to satisfy workloads. In those situations, the implementation of HACCP is far more complicated due to the difficulty of controlling basic sanitary standards [19].

Our results suggest that food product plants in Korea were more likely to implement HACCP to improve hygiene ability rather than for other reasons. This result might be related with some reasons. First, Korean consumers showed increased the knowledge about food hygiene result from bovine spongiform encephalopathy (BSE), foot and mouth disease (FMD), and avian Influenza (AI) etc. Secondly, food hygiene might be the most important factors for livestock product plants employers and employees because SSOP was compulsorily applied for food products processing plant in Korea.

Table 4 represents the job satisfaction in HACCP system operators by gender, age, size of food product facilities, service period, and position. Approximately $83 \%$ of respondents indicated that they were satisfied with their jobs. Overall, both male and female were satisfied with their jobs. The proportion of male who thought of themselves as "Agree" in job satisfaction is higher than that of female. Concerning the age, the highest proportion of "Agree" was the age group 40-49 (100\%) whereas the highest that of "Disagree" was the age group 20-29 (15.7\%); however the job satisfaction increased with linearly age. The proportion of workers at large scale company who thought of themselves as "Agree" in is higher than that of small scale one. Regarding service period, there was a Ushaped association between service period and job satisfaction although there was no significant difference across the service period. The highest proportion of "Agree" by position was team manager and over (100.0\%), whereas employees were the lowest (13.8\%). The Chi-square test showed that the gender, age, livestock product facilities, and position significantly affected to job satisfaction ( $\mathrm{p}<$ 0.001 ). The respondents showed an optimistic attitude on job satisfaction as HACCP system operator.

Table 5 depicts the prospect of occupation in HACCP system operators by gender, age, size of food product

Table 4 Job satisfaction in HACCP system operators by gender, age, size of facilities, service period, and position

\begin{tabular}{|c|c|c|c|c|c|c|c|c|}
\hline & & Disagree (\%) & Moderate (\%) & Agree (\%) & Total $(\mathrm{N})$ & $x^{2}$ & df & $p$ \\
\hline \multirow[t]{3}{*}{ Gender } & Male & $11(10.8)$ & $6(5.9)$ & $85(83.3)$ & 102 & 39.353 & 2 & 0.000 \\
\hline & Female & $0(0)$ & 23(47.9) & $25(52.1)$ & 48 & & & \\
\hline & Total & $11(7.3)$ & 29(19.3) & $110(73.3)$ & 150 & & & \\
\hline \multirow[t]{4}{*}{ Age (yrs) } & $20-29$ & $11(15.7)$ & $15(21.4)$ & $44(62.9)$ & 70 & 24.442 & 4 & 0.000 \\
\hline & $30-39$ & $0(0)$ & $14(28.0)$ & $36(72.0)$ & 50 & & & \\
\hline & $40-49$ & $0(0)$ & $0(0)$ & $30(100.0)$ & 30 & & & \\
\hline & Total & $11(7.3)$ & 29(19.3) & $110(73.3)$ & 150 & & & \\
\hline \multirow[t]{3}{*}{ Size of facilities } & Large-scale & $0(0)$ & $0(0)$ & $40(100.0)$ & 40 & 19.835 & 2 & 0.000 \\
\hline & Small-scale & $11(10.0)$ & $29(26.4)$ & $70(63.6)$ & 110 & & & \\
\hline & Total & $11(7.3)$ & 29(19.3) & $110(73.3)$ & 150 & & & \\
\hline \multirow[t]{4}{*}{ Service period (yrs.) } & $<1$ & $11(12.9)$ & $15(17.6)$ & $59(69.4)$ & 85 & 14.039 & 4 & 0.007 \\
\hline & $3-5$ & $0(0)$ & $0(0)$ & 13(100.0) & 13 & & & \\
\hline & $5-10$ & $0(0)$ & $14(26.9)$ & $38(73.1)$ & 52 & & & \\
\hline & Total & $11(7.3)$ & 29(19.3) & $110(73.3)$ & 150 & & & \\
\hline \multirow[t]{5}{*}{ Position } & President, Director & $0(0)$ & $0(0)$ & $2(100.0)$ & 2 & 42.727 & 6 & 0.000 \\
\hline & Assistant manager & $0(0)$ & $0(0)$ & $42(100.0)$ & 42 & & & \\
\hline & Team manager & $0(0)$ & $0(0)$ & $26(100.0)$ & 26 & & & \\
\hline & Employees & $11(13.8)$ & $29(36.3)$ & $40(50.0)$ & 80 & & & \\
\hline & Total & $11(7.3)$ & 29(19.3) & 110(73.3) & 150 & & & \\
\hline
\end{tabular}


Table 5 Prospect of occupation in HACCP system operators by gender, age, size of facilities, service period, and position

\begin{tabular}{|c|c|c|c|c|c|c|c|}
\hline & & Moderate (\%) & Agree (\%) & Total $(\mathrm{N})$ & $\mathrm{x}^{2}$ & df & $p$ \\
\hline \multirow[t]{3}{*}{ Gender } & Male & 13(12.7) & $89(87.3)$ & 102 & 5.963 & 1 & 0.015 \\
\hline & Female & $14(29.2)$ & $34(70.8)$ & 48 & & & \\
\hline & Total & $27(18.0)$ & 123(82.0) & 150 & & & \\
\hline \multirow[t]{4}{*}{ Age (yrs) } & $20-29$ & $0(0)$ & $70(100.0)$ & 70 & 24.442 & 4 & 0.000 \\
\hline & $30-39$ & $227(54.0)$ & $23(46.0)$ & 50 & & & \\
\hline & $40-49$ & $0(0)$ & $30(100.0)$ & 30 & & & \\
\hline & Total & $27(18.0)$ & 123(82.0) & 150 & & & \\
\hline \multirow[t]{3}{*}{ Size of facilities } & Large-scale & $0(0)$ & $40(100.0)$ & 40 & 11.973 & 1 & 0.001 \\
\hline & Small-scale & $27(24.5)$ & $83(75.5)$ & 110 & & & \\
\hline & Total & $27(18.0)$ & 123(82.0) & 150 & & & \\
\hline \multirow[t]{4}{*}{ Service period (yrs.) } & $<1$ & $0(0)$ & $85(100.0)$ & 85 & 62.054 & 2 & 0.000 \\
\hline & $3-5$ & $0(0)$ & 13(100.0) & 13 & & & \\
\hline & $5-10$ & 27(51.9) & $25(48.1)$ & 52 & & & \\
\hline & Total & $27(18.0)$ & 123(82.0) & 150 & & & \\
\hline \multirow[t]{5}{*}{ Position } & President, Director & $0(0)$ & $2(100.0)$ & 2 & 27.710 & 3 & 0.000 \\
\hline & Assistant manager & $0(0)$ & $4(100.0)$ & $4(100.0)$ & & & \\
\hline & Team manager & 13(50.0) & $13(50.0)$ & $26(100.0)$ & & & \\
\hline & Employees & $14(17.5)$ & $66(82.5)$ & $80(100.0)$ & & & \\
\hline & Total & $27(18.0)$ & 123(82.0) & 150 & & & \\
\hline
\end{tabular}

facilities, service period, and position. The same trends shown in Table 4 were observed except for service period. A total of $82 \%$ of respondents showed optimistic prospect of occupation. Subjects aged 20-29 and 40-49 reported that HACCP system operator would be hopeful, whereas those aged 30-39 thought of the same as now. Furthermore, it was higher than those aged 20-29 and 40-49. The proportion of workers at large scale who thought of themselves as "Agree" in is higher than that of small scale. Regarding service period, the lowest proportion of "Agree" by career was 5-10 years group and over (48.1\%), whereas less than 1 and 3-5 years group were the highest (100.0\%). Especially, the prospect of occupation in HACCP system operator decreased with service period and there was significant difference across service period. The results of Chi-square testing showed that there were significant differences in the prospect of occupation in HACCP system operator by the gender $(\mathrm{p}<0.015)$, age, livestock product facilities, service period, and position $(\mathrm{p}<0.001)$.

The main role of HACCP system operators is to encourage and motivate supervisory staff and food handlers on different aspects of the HACCP concept. Consequently, they will need to attribute responsibilities between personnel involved with the implementation of the system. This must be done in accordance to the difficulty of the operation and the capabilities of the person who is going to be responsible for it [19].

\section{Conclusions}

In conclusion, most of respondents answered an optimistic attitude on job satisfaction as HACCP system operator. The respondents from HACCP system operator were also showed optimistic prospect of occupation. Results from this study could be used to better educate HACCP system operators and industry implementers.

\section{Competing interests}

The authors declare that they have no competing interests.

\section{Authors' contributions}

DGL carried out the HACCP survey including the design of the study and all authors participated in and drafted the manuscript. JHK performed the statistical analysis and all authors read and approved the final manuscript.

\section{Acknowledgement}

This study was financially supported by a grant from Jinju Health College Research Foundation.

\section{Author details}

'Department of Public Health, Graduate School of Public Health, Seoul National University, Seoul 151-742, Korea. ${ }^{2}$ Department of Animal Science and Technology, Sunchon National University, Suncheon 540-742, Korea. ${ }^{3}$ Department of Agricultural Biotechnology and Research Institute of Agriculture and Life Science, Seoul National University, Seoul 151-921, Korea. ${ }^{4}$ Department of Health Administration and Food Hygiene, Jinju Health College, Jinju 660-757, Korea.

Received: 30 April 2014 Accepted: 16 July 2014 Published: 24 September 2014 


\section{References}

1. Al-Kandari D, Jukes JD: Incorporating HACCP into national food control systems analyzing progress in the United Arab Emirates. Food Control 2011, 22:851-861.

2. Codex Alimentarius Commission (CAC): Recommended international code of practice: General principles of food hygiene; 2003. CAC/RPP 1e1969, Revision 4.

3. Wallace C, Powell S, Holyoak L: Development of methods for standardized HACCP assessment. Brit Food J 2005, 107(10):723-742.

4. Ropkins K, Beck A: Evaluation of worldwide approaches to the use of HACCP to control food safety. Trends in Food Sci Technol 2000, 11:10-21.

5. Codex Alimentarius Commission (CAC): Food hygiene basic texts. Codex Alimentarius -Joint FAO/WHO food standards programs. 3rd edition. Lanham, MD: Bernan Association; 2001.

6. QIA: Animal Plant and Fisheries Quarantine and Inspection Agency. Republic of Korea; 2012. Available: http://www:qia.go.kr/livestock/clean/ livestock_livestock_food.jsp.

7. Taylor E: HACCP in small companies: benefit or burden. Food Control 2001, 12:217-222.

8. Holt G: Researcher investigating barriers to the implementation of GHP in SMEs. Personal Communication; 1999. Oct. 1999.

9. Moon HK, Ryu K: Usage status survey on some essential facilities, equipment and documentary records for HACCP implementation in contract foodservice. J Kor Soc Food Sci Nutr 2004, 33:1162-1168.

10. Kim GM, Lee SY: A study on the sanitation management status and barriers to HACCP system implementation of school foodservice institutions in Seoul metropolitan area. J Comm Nutr 2008, 13:405-417.

11. Park JS, Park SI: A survey of washing and sanitizing methods for the pre-preparation of fruits at a school foodservice in the Seoul and Kyunggi area. Kor J Food Ctr 2009, 24:39-50

12. Kwak CK, Kim TK, Park SH, Jang JK: Economic feasibility of HACCP at slaughter plants. Korean J Agr Econ 2002, 29:1-18.

13. Hong $\mathrm{CH}$, Cho DH: Comparative analysis of the prerequisite items applicable to the HACCP in livestock processing plants. J Food Hygiene Safety 2008, 23:19-25.

14. Codex Alimentarius Commission (CAC): Recommended International Code of Practice-General Principles of Food Hygiene; 1997. CAC/RCP 1-1969, Rev.3 and anex.

15. Panisello PJ, Quantick PC, Knowles MJ: Towards the implementation of HACCP; results of a UK regional survey. Food Control 1999, 10:87-90.

16. Mortlock MP, Peters AC, Griffith C: Food hygiene and hazard analysis critical control point in the United Kingdom food industry: practices, perceptions and attitudes. J Food Prot 1999, 62:786-792.

17. Gormley RT: RTD needs and opinions of European food SMEs. Farm and Food 1995, 5:27-30.

18. NACMCF: Generic HACCP for raw beef. The national advisory committee on microbiological criteria for food. Food Microbiol 1993, 10:449.

19. Panisello PJ, Quantick PC: Technical barriers to HACCP. Food Control 2001, 12:165-173

20. World Health Organization (WHO): Training Considerations for the Application of the Hazard Analysis Critical Control Points System to Food Processing and Manufacturing, WHO Document, WHO/FNU/FOS/93.3, Division of Food and Nutrition. Geneva: WHO; 1993.

21. Wallace C, Williams T: Pre-requisites: A help or a hindrance to HACCP. Food Control 2001, 12:235-240.

22. Seward S: Application of HACCP in food service. Irish J Agr Food Res 2000, 39:221-227.

23. Forsythe SJ, Hayes PR: Food hygiene, microbiology and HACCP. 3rd edition. Maryland: Aspen; 1998

doi:10.1186/2055-0391-56-19

Cite this article as: Kim et al.: Perception of the HACCP system operators on livestock product manufacturers. Journal of Animal Science and Technology 2014 56:19.

\section{Submit your next manuscript to BioMed Central and take full advantage of:}

- Convenient online submission

- Thorough peer review

- No space constraints or color figure charges

- Immediate publication on acceptance

- Inclusion in PubMed, CAS, Scopus and Google Scholar

- Research which is freely available for redistribution

Submit your manuscript at www.biomedcentral.com/submit
Biomed Central 